\title{
Lelang Jabatan Sebagai Inovasi Dalam Penempatan Aparatur Sipil Negara di Indonesia
}

\author{
Taufik ${ }^{1}$ \\ 1 Prodi Ilmu Administrasi Negara UIN Ar-Raniry Banda Aceh Jalan Syeikh Abdul Rauf \\ Darussalam, Banda Aceh.
}

\begin{abstract}
The high political intervention of the bureaucracy in this case the placement of the state Civil Apparatus (ASN) has an impact on ASN's inneutrality in the elections involved in practical politics. This is because solely to get the position of positions when the candidate he supported was elected as the head of the district. This article aims to analyze the innovation of the open recruitment policy of ASN. The implementation of high Leadership (JPT) (auction) in Indonesia is generally done well in accordance with merit system, namely based on qualifications, competence, and performance in a fair and reasonable manner with no distinction of political background, race, color, religion, origin, sex, marital status, age, or condition of disability. However, this open recruitment system has not yet decided the chain of political intervention against bureaucracy. The results of the JPT recruitment were handed over to the personnel recruitment officers who were in fact held by political officials. Thus, it is difficult to separate political and administrative dichotomy. In addition, there are still weaknesses in this open recruitment, such as expensive costs, restrictions or (demarcation) of prospective participants of the JPT recruitment, and take a long time. Therefore, this policy needs to be reviewed to not only produce the competent ASN, but also free from political intervention.
\end{abstract}

Keywords: employee placement, ASN, open recruitment, job auction.

\section{Pendahuluan}

Aparatur Sipil Negara (ASN) merupakan unsur penting dalam melaksanakan roda pemerintahan. ASN juga dijuluki sebagai "mesin" birokrasi yang menggerakkan sumber daya-sumber daya yang tersedia untuk mewujudkan tujuan dan sasaran organisasi pemerintah. Menyadari pentingnya peran aparatur sipil negara, pemerintah telah menerbitkan UU No. 5 tahun 2014 tentang Aparatur Sipil Negara yang merupakan upaya dalam melakukan reformasi birokrasi bidang sumber daya manusia aparatur. Namun dalam UU baru ini menekankan perubahan yang fundamental dibandingkan dengan peraturan kepegawaian sebelumnya.

Perubahan-perubahan yang terdapat dalam Undang-undang Nomor 5 Tahun 2014 pada pokoknya ditujukan untuk membangun Aparatur Sipil Negara yang memiliki integritas, profesional, netral dan bebas dari intervensi politik, bersih dari praktik korupsi, kolusi dan nepotisme, serta mampu menyelenggarakan pelayanan publik bagi masyarakat.

Masalah utama dalam aparatur negara khususnya bidang SDM di Indonesia saat ini adalah

*)Corresponding Author 
alokasi dalam hal kuantitas, kualitas, dan distribusi aparatur menurut teritorial (daerah) tidak seimbang, serta tingkat produktivitas PNS masih rendah. Manajemen sumber daya manusia aparatur belum dilaksanakan secara optimal untuk meningkatkan profesionalisme, kinerja pegawai, dan organisasi (Grand Design RB 2010-2025). Oleh karena itu, hal ini menjadi perhatian penting bagi pemerintah bagaimana meningkatkan produktivitas dan pengembangan kapasitas SDM aparatur melalui reformasi birokrasi. Hasil reformasi tersebut diharapkan SDM aparatur yang berintegritas, netral, kompeten, capable, profesional, berkinerja tinggi, dan sejahtera.

Dilihat dari penilaian kinerja pemerintah Indonesia di tingkat global, yaitu berdasarkan Government Effectiveness Indeks yang diliris oleh World Bank tahun 2018 belum menunjukkan perubahan yang signifikan. Indonesia menduduki posisi 75 dari 193 jumlah negara. Posisi ini masih tertinggal jauh bila dibandingkan dengan negara tetangga, seperti Singapore berada posisi (1), Malaysia (35), Taiwan (24) Brunei posisi (26), dan Thailand (60). Data ini menunjukkan bahwa keberhasilan suatu pemerintahan sangat dipengaruhi oleh kualitas sumber daya manusia aparatur itu sendiri. Kemudian, daya saing Indonesia juga mengalami penurunan.

Sementara itu, dari sisi daya saing global menurut data Global Competetive Indeks tahun 2019, posisi Indonesia turun lima peringkat dari tahun sebelumnya menjadi peringkat 50 dari 141 jumlah negara di dunia. Posisi tersebut menunjukkan bahwa kapasitas kelembagaan atau efektivitas pemerintahan di Indonesia masih tertinggal jika dibandingkan dengan kemajuan yang dicapai oleh negaranegara tetangga.

Data di atas menunjukkan adanya permasalahan dalam tata kelola ASN yang belum optimal. Kemudian masih maraknya intervensi politik dalam penempatan ASN kian mewarnai wajah birokrasi di Indonesia. Berdasarkan hasil survei bidang pengkajian dan pengembangan sistem lembaga Komisi Aparatur Sipil Negara (KASN) tahun 2018 menunjukkan bahwa motif ASN tidak netral dalam pemilukada dikarenakan untuk mendapatkan/mempertahankan jabatan/materi/proyek menunjukkan persentase yang sangat tinggi, yaitu 43,4 \%. Sedangkan motif karena adanya hubungan kekeluargaan hanya 15,5\% (KASN, 2018).

Menyikapi permasalahan tersebut, pemerintah melalui Kementerian Pendayagunaan Aparatur Negara dan Reformasi Birokrasi telah melakukan inovasi dalam pengisian jabatan ASN, yaitu melalui seleksi terbuka (open recruitmen) atau lazimnya dikenal dengan sebutan lelang Jabatan. Melalui Permenpan-RB No. 13 Tahun 2014 tentang Tata Cara Pengisian JPT Pada Instansi Pemerintah. Inovasi dari kebijakan ini merupakan pedoman bagi instansi pemerintah Pusat dan Daerah dalam penyelenggaraan pengisian JPT Utama, Madya dan Pratama secara terbuka. Tujuan yang akan dicapai dari inovasi kebijakan ini adalah terselenggaranya pengisian JPT Utama, Madya dan Pratama yang transparan, objektif, kompetitif dan akuntabel. Harapannya JPT yang terpilih sesuai dengan kompetensi 
yang dibutuhkan pada jabatan yang didudukinya sesuai dengan sistem merit, yaitu mengedepankan asas profesionalisme dan menghindari dari intervensi politik.

Berdasarkan permasalahan di atas, untuk menghindari transaksi jual beli jabatan, intervensi jabatan, maupun praktik lainnya terhadap penempatan jabatan ASN, maka tulisan ini bertujuan untuk menganalisis inovasi kebijakan dalam seleksi terbuka jabatan ASN di beberapa daerah berdasarkan penelusuran literatur hasil penelitian.

\section{Metode Penelitian}

Penelitian ini menggunakan metode deskriptif kualitatif, dengan jenis penelitian kepustakaan (library research). Penelitian pustaka merupakan serangkaian kegiatan yang berkenaan dengan metode pengumpulan data pustaka, membaca, dan mencatat serta mengolah bahan penelitian (Zed, 2004). Desain penelitian dilakukan melalui beberapa tahapan, yaitu sebagai berikut: pertama, menelusuri, mencatat, dan membaca berbagai temuan terkait pembahasan lelang jabatan atau seleksi terbuka jabatan ASN secara umum pada setiap pembahasan hasil penelitian, artikel, maupun laporan dari lembaga yang relevan dengan kajian yang didapatkan dalam literatur-literatur, dan sumber website lembaga resmi pemerintah, maupun lembaga internasional, serta sumber-sumber lainnya yang relevan dengan studi ini.

Kedua, memadukan segala temuan, baik teori, model maupun konsep penempatan pegawai ASN. Ketiga, menganalisis setiap temuan dari berbagai bacaan, baik dari sisi kelebihan, kekurangan, maupun keterkaitan tentang tulisan yang dibahas. Tahapan terakhir adalah memberikan gagasan kritis dengan mengelaborasi pendekatan yang berbeda dari temuan dalam artikel sebelumnya.

\section{Hasil dan Pembahasan \\ Konsep Penempatan Pegawai Pengertian Penempatan Pegawai}

Dalam literatur manajemen dijelaskan awal mulanya konsep penempatan pegawai diperkenalkan Henry Fayol, salah satu tokoh manajemen klasik yang mengemukakan konsep 14 prinsip manajemen. Salah satu prinsip di dalamnya adalah pembagian kerja (division of work). Spesialisasi pekerjaan kepada individu-individu dalam lingkaran manajemen untuk membangun sebuah pengalaman dan terus mengasah keahliannya sehingga pada akhirnya individu-individu tersebut bisa menjadi lebih produktif dan menguntungkan (Handoko, 2012). Melalui pembagian kerja berdasarkan spesialisasi pekerjaan, kemudian dikembangkan pada saat ini menjadi konsep penempatan pegawai.

Penempatan merupakan langkah selanjutnya setelah proses penyaringan selesai. Menurut Siagian (2003) penempatan merupakan akhir dari seleksi. Menurut pandangan ini, jika seluruh proses seleksi telah ditempuh dan lamaran seseorang diterima, akhirnya seseorang memperoleh status sebagai pegawai dan ditempatkan pada posisi tertentu untuk melaksanakan tugas atau pekerjaan tertentu pula. Pandangan demikian memang tidak salah sepanjang menyangkut pegawai baru.

Hanya saja teori manajemen sumber daya manusia yang mutakhir menekankan bahwa penempatan tidak hanya berlaku bagi para 
pegawai baru, akan tetapi berlaku pula bagi para pegawai lama yang mengalami alih tugas dan mutasi. Berarti konsep penempatan mencakup promosi, transfer dan bahkan mutasi sekalipun. Hasibuan (2001) mengemukakan penempatan kerja merupakan tindak lanjut dari seleksi, yaitu menempatkan calon pegawai yang diterima (lulus seleksi) pada jabatan/pekerjaan yang membutuhkan dan sekaligus mendelegasikan author kepada orang tersebut.

(Schuler \& Jackson 1997) mengemukakan penempatan (placement) berkaitan dengan pencocokan seorang dengan jabatan yang akan dipegangnya. Hasibuan (2001) menegaskan bahwa penempatan hendaklah memperhatikan : asas penempatan orang-orang yang tepat dan penempatan orang yang tepat untuk jabatan yang tepat atau "the right man in the right place and the right man behind the right job".

Faktor-Faktor

Pegawai

Penempatan

Schuler \& Jackson (1997) mengemukakan terdapat faktorfaktor yang harus dipenuhi dalam penempatan kerja, yaitu sebagai berikut:

\section{a. Pengetahuan}

Pengetahuan merupakan

segala hal yang pernah diketahui tentang suatu objek tertentu. Pengetahuan merupakan suatu kesatuan yang terorganisir yang biasanya terdiri dari fakta atau prosedur yang diterapkan secara langsung terhadap kinerja dari sebuah fungsi. Pengetahuan seseorang dapat diperoleh melalui pendidikan formal, informal, membaca buku dan lain-lain. Pengetahuan yang dimiliki ASN diharapkan dapat membantu dalam melaksanakan tugas dan tanggung jawab pekerjaannya. Oleh karena itu, ASN dituntut untuk memiliki pengetahuan yang sesuai dengan jenis pekerjaannya sehingga akan membutuhkan waktu yang singkat untuk mempelajari tugas-tugas yang menjadi tanggung jawabnya dan mengurangi biaya dalam pelaksanaan pelatihan terhadap upaya peningkatan prestasi kerjanya. Pengetahuan seorang pegawai dapat dilihat pada tingkat kreativitasnya dalam menyelesaikan pekerjaan maupun kemampuannya dalam menciptakan ide baru yang dapat mendukung tercapainya tujuan organisasi.

\section{b. Keterampilan}

Keterampilan berasal dari kata terampil yang berarti cakap, mampu, dan cekatan dalam menyelesaikan tugas dan pekerjaannya. Hasil berdasarkan keterampilan meliputi pengembangan keterampilan teknik. keterampilan itu jelas terlihat pada perilaku. Dengan perubahan yang cepat dalam teknologi dan sistem pelaksanaan dalam kantor dan manajerial yang memperbarui teknologi dan pembentukan keterampilan telah menjadi dorongan utama dalam pelatihan. Keterampilan komunikasi, melaksanakan penilaian kerja, pembentukan tim, kepemimpinan juga semakin meningkat permintaannya.

Latihan untuk jenis-jenis keterampilan antar perorangan juga penting bagi para ASN yang berhubungan dengan masyarakat, seperti dalam memberikan pelayanan. Dengan meningkatnya keterampilan ASN maka diharapkan pekerjaan dapat diselesaikan sesuai dengan rencana sebelumnya, sebab menguasai kemampuan tertentu 
dalam bekerja, sehingga di harapkan tidak diperlukan pengawasan karena hambatan dalam menyelesaikan pekerjaan teratasi. Keterampilan terdiri dari fisik maupun non fisik. Keterampilan fisik dibutuhkan untuk pekerjaan-pekerjaan fisik, misalnya mengoperasikan komputer dan sebagainya. Keterampilan non fisik dibutuhkan untuk mendapatkan sesuatu yang sudah jadi, misalnya kemampuan memimpin rapat, membangun komunikasi dan mengelola hubungan dengan orang lain secara efektif.

\section{c. Kemampuan}

Kemampuan kerja merupakan kemampuan dalam menyelesaikan tugas dan tanggung jawabnya. Kemampuan kerja diperlukan karena dengan kemampuan pegawai tujuan organisasi dapat dicapai. Kemampuan terdiri dari kemampuan kognitif dan kemampuan fisik, yang bisa diperoleh dari pengetahuan, pengalaman kerja, keterampilan kerja. Sebelum menempatkan ASN hendaknya memperhatikan kemampuan yang dimiliki, karena apabila pegawai tidak memiliki kemampuan dalam pelaksanaan pekerjaannya maka akan menghambat pelaksanaan tugas yang diberikan kepadanya. Dan dengan menempatkan pegawai sesuai dengan kemampuan kerja yang dimiliki dapat menunjang pelaksanaan kerja sehingga dapat mencapai hasil yang maksimal.

\section{d. Kepribadian}

Aparatur akan bekerja dengan rajin dan tekun apabila yang dikerjakan sesuai dengan minatnya. Penempatan berdasarkan kepribadian dengan melihat minat dan wataknya, maka dapat membuat ASN puas dan mempunyai semangat kerja yang sangat tinggi. Dalam penempatan kerja faktor sikap hendaknya menjadi pertimbangan bagi manajemen sumber daya manusia, karena hal tersebut berpengaruh secara langsung baik bagi individu dan organisasi maupun bagi masyarakat sebagai pengguna jasa dari organisasi itu sendiri. Kepribadian seseorang menyangkut beberapa dimensi, yaitu Ekstraversi (social, talkactive, assertive), Agreeableness (good nature, kooperatif, dapat dipercaya), Conscientiousness (tanggungjawab, mandiri, gigih, berorientasi pada hasil), stabilitas dan instabilitas emosi (ketegangan, merasa kurang aman, gugup), keterbukaan terhadap pengalaman (penuh imajinasi, mempunyai perasaan seni, intelektual).

$$
\text { Pelaksanaan manajemen }
$$
aparatur sipil negara belum berdasarkan pada perbandingan antara kompetensi dan kualifikasi yang diperlukan oleh jabatan dengan kompetensi dan kualifikasi yang dimiliki calon dalam rekrutmen, pengangkatan, penempatan, dan promosi pada jabatan sejalan dengan tata kelola pemerintahan yang baik dan untuk mewujudkan aparatur sipil negara sebagai bagian dari reformasi birokrasi, perlu ditetapkan aparatur sipil negara sebagai profesi yang memiliki kewajiban mengelola dan mengembangkan dirinya dan wajib mempertanggungjawabkan

kinerjanya dan menerapkan prinsip merit dalam pelaksanaan manajemen aparatur sipil negara.

Untuk dapat menjalankan tugas pelayanan publik, tugas pemerintahan, dan tugas pembangunan tertentu, pegawai ASN harus memiliki profesi dan Manajemen ASN yang berdasarkan pada Sistem Merit atau perbandingan 
antara kualifikasi, kompetensi, dan kinerja yang dibutuhkan oleh jabatan dengan kualifikasi, kompetensi, dan kinerja yang dimiliki oleh calon dalam rekrutmen, pengangkatan, penempatan, dan promosi pada jabatan yang dilaksanakan secara terbuka dan kompetitif, sejalan dengan tata kelola pemerintahan yang baik.

\section{Potret Penempatan ASN di Indonesia}

Penempatan ASN di Indonesia saat ini umumnya masih kuat intervensi politik, melalui politisasi birokrasi. Politisasi birokrasi merupakan upaya memobilisasi birokrat (oleh kandidat kepala daerah/politisi) dalam rangka memenangkan calon kepala daerah. Politisasi birokrasi melibatkan petahana, tim sukses dan anggota legislatif (DPRD) pendukung kandidat kepala daerah.

Bentuk politisasi birokrasi yang kerap terjadi antara lain, mulai dari penyalahgunaan program dan anggaran, mobilisasi, sampai pada intervensi politik dalam penempatan jabatan seperti mutasi, demosi, dan promosi (Basyar, 2018). Ketiga bentuk yang kerap terjadi politisasi birokrasi lebih lanjut Basyar (2018) menjelaskan, sebagai berikut; Pertama, pemanfaatan program dan anggaran. Proses program kebijakan dan alokasi anggaran di masingmasing Organisasi Perangkat Daerah (OPD) rentan digunakan petahana sebagai instrumen kampanye. Misalnya, pemberian dana hibah dan bantuan sosial kepada masyarakat atau pemerintahan desa untuk mendapat dukungan.

$\begin{array}{lccr}\text { Modus ini terjadi } & \text { karena } \\ \text { betapa kuatnya } & \text { otoritas kepala } \\ \text { daerah dan } & \text { DPRD } & \text { untuk } \\ \text { menganggarkan dan menyetujui }\end{array}$

proposal. Selain itu, cara ini juga sering dipakai karena ketiadaan pembatasan alokasi anggaran dan lemahnya pengawasan perencanaan dan pengelolaan dana hibah dan bantuan sosial (KPK, 2014).

Kedua, penempatan jabatan. Jabatan merupakan instrumen strategis lain yang kerap dimanfaatkan kandidat, terutama petahana) dalam mengamankan kekuasaan. Pengisian jabatan struktur pemerintah daerah bukan tanpa intensi dari kepala daerah; bisa sebagai imbalan karena mendukung kepala daerah terpilih (pasca pilkada), bisa juga sebagai "tuntutan" untuk mendukung pemberi jabatan (petahana) dalam pilkada berikutnya (jelang pilkada). Karena itu, proses demosi, mutasi, dan promosi jabatan sangat bergantung pada kontrusi birokrat pada masa pilkada.

Ketiga, tekanan tim sukses kandidat. Tim sukses merupakan informan bagi kandidat terkait arah dukungan birokrat (ASN). Kehadiran tim sukses dalam kegiatan-kegiatan Pemda atau dalam forum-forum informal sering kali untuk menggali informasi sekaligus menekan birokrat untuk mendukung petahana. Selain itu, tim sukses juga merupakan perpanjangan tangan kandidat (petahana) dalam memobilisasi birokrat lewat intervensi program dan kegiatan di pemerintah daerah.

Persoalan kepala daerah sebagai PPK menjadi semakin pelik ketika dia sulit melepas jubah politiknya dalam memimpin birokrasi. Sudah menjadi rahasia publik, keberhasilan seorang politisi menduduki tahta kekuasaan di daerah tidak terlepas dari dukungan partai politik. Memang perlu diakui bahwa saat ini, sudah ada kepala 
daerah yang berasal dari jalur perseorang. Namun, peran politik atau partai politik masih menjadi faktor determinan dalam proses kontestasi di daerah.

$$
\text { Kondisi ini sangat }
$$

mempengaruhi kepala daerah (terpilih) dalam pengaturan jabatan di daerah. Penempatan jabatan birokrat sangat ditentukan oleh seberapa besar dampaknya bagi kekuasaan atau partai politik pendukung. Kalkulasi untung-rugi bagi partai politik atau politisi sangat kuat terasa dalam proses promosi, mutasi dan demosi jabatan di daerah. Kondisi ini membuat ASN kesulitan untuk menjunjung tinggi netralitas dalam proses pilkada (Basyar, 2018).

\section{Inovasi Penempatan Pegawai ASN melalui Seleksi Terbuka}

Inovasi dalam sektor publik menjadi sebuah keniscayaan seiring dengan semangat perjuangan dalam melakukan reformasi birokrasi. Konsep inovasi dalam kajian administrasi publik tertuang dalam perspektif New Public Management dan Reinventing Government (Taufik, \& Astuti, 2019). Konsep ini menjelaskan bagaimana kemampuan organisasi untuk survive dan meningkatkan kinerja dengan mengadopsi semangat yang dijalankan dalam sektor swasta ke sektor publik (Osborne \& Gaebler 1992). Mengadopsi semangat kerja di sektor swasta telah banyak melahirkan berbagai inovasi-inovasi yang dapat dikembangkan di sektor publik.

Salah satu tokoh manajemen (Mintzberg, 2000) mengemukakan pengertian inovasi sebagai" To innovate means to break away from established patterns, so the innovative organization cannot rely on any form of standardization for coordination". Mintzberg menekankan bahwa dalam berinovasi harus berani mengubah pola yang sudah ada, sehingga organisasi yang berinovatif tidak kaku pada standarisasi dan peraturan yang ada.

Pandangan lain mengenai pengertian inovasi dikemukakan oleh (Lynn, 1997) yang menjelaskan bahwa inovasi (dalam organisasi pemerintah) merupakan transformasi dari fungsi utama organisasi dan perubahan yang permanen dan mendasar dalam struktur organisasi .Berkenaan dengan hal itu, (Rogers, 2003) juga berpendapat bahwa "an innovation is an idea, practice, or object that is perceived as new by individual or other unit of adopter". Pandangan dari Rogers melihat sebuah inovasi dapat dimaknai sebagai sebuah ide, praktek, atau objek yang dianggap baru oleh individu atau satu unit adopsi lainnya. Pengertian inovasi dari Rogers ini menunjukkan bahwa inovasi dapat berupa sebuah temuan baru atau juga berupa adopsi dari inovasi lainnya. Dari pengertian inovasi di atas dapat disimpulkan bahwa inovasi dapat berupa sebuah ide, gagasan, cara, atau metode yang lama dengan yang baru yang fleksibel, dan mempunyai sifat membangun ke arah yang lebih baik. Inovasi dapat berupa dilihat dari sisi manajemen maupun kebijakan publik.

Secara konseptual, (G.Mulgan, \& Albury, 2003) membagi inovasi kebijakan publik dalam tiga kategori, yaitu: a). Policy innovation: new policy direction and initiatives, yaitu inovasi kebijakan yang dimaksud adalah adanya inisiatif dan arah kebijakan baru. Ini dapat diartikan bahwa setiap kebijakan publik yang dikeluarkan pada prinsipnya harus 
dapat memuat sesuatu yang baru. b). Innovation in the policy making process, yaitu inovasi yang dapat memengaruhi proses pembuatan atau perumusan kebijakan. c). Policy to foster innovation and its diffusion, yaitu kebijakan yang dimaksud adalah kebijakan yang khusus diciptakan untuk mendorong, mengembangkan, dan menyebarkan inovasi untuk berbagai sektor.

Berdasarkan pendapat (Mulgan \& Albury, 2003) seleksi terbuka jabatan ASN dapat digolongkan dalam kategori policy innovation: new policy direction and initiatives. Hal ini dikarenakan proses seleksi jabatan ASN dilakukan secara terbuka merupakan sebuah inisiatif baru, yang sebelumnya dilakukan secara terbatas dan tertutup. Potret penempatan pegawai ASN sebagaimana dijelaskan di atas menimbulkan perhatian pemerintah untuk menyelesaikan ancaman intervensi politik terhadap penempatan pegawai ASN di Indonesia. Berkaitan dengan hal itu, pemerintah telah berinovasi dalam menghasilkan sebuah kebijakan baru untuk seleksi terbuka jabatan pimpinan tinggi pada instansi pemerintah.

Melalui seleksi secara terbuka (lelang) dan kompetitif, maka pengisian jabatan pimpinan tinggi pada instansi pemerintah lebih mengutamakan kompetensi sebagai syarat utama untuk menduduki JPT. Seleksi terbuka dianggap lebih sehat ditimbang masih menggunakan sistem lama. Bila sebelumnya pola spoil system lebih dominan dalam penempatan seseorang pada jabatan birokrasi, maka melalui seleksi terbuka tersebut merupakan upaya mewujudkan "the right man in the right place". Dalam pelaksanaan pengisian JPT tersebut, KASN memiliki kewenangan melakukan pengawasan terhadap seluruh proses tahapan pelaksanaan seleksi tersebut.

Berdasarkan hasil kajian yang dilakukan oleh (Irfan, 2017) terdapat beberapa kelebihan dari seleksi terbuka jabatan ASN, yaitu: Pertama, upaya merit system. Terbitnya UU ASN telah mengubah pengembangan ASN dari pendekatan closed career system kepada open career system yang mengedepankan kompetisi dan kompetensi dalam promosi dan pengisian jabatan. Sistem karier terbuka memberikan peluang bagi PNS yang telah memenuhi persyaratan mengikuti seleksi pengisian JPT di luar instansinya. Dengan demikian, terbuka luas bagi setiap PNS yang memiliki kompetensi tertentu untuk mengembangkan karirnya di lingkup instansi pemerintah Pusat maupun Daerah. Kedua, mempercepat regenerasi. Pengisian jabatan JPT menjadi hal urgen untuk segera dilakukan apabila ada jabatan yang kosong (lowong) di suatu instansi pemerintah. Hal ini agar pelaksanaan program dan kegiatan administrasi dan kepemerintahan dapat berjalan dengan baik dan tidak terabaikan.

Adanya pengaturan seleksi terbuka menjadi pendorong sekaligus pedoman dalam mempercepat pengisian JPT di instansi pemerintah. Bahkan, untuk mempercepat proses seleksi terbuka JPT, Presiden telah mengeluarkan instruksinya melalui Inpres Nomor 3 Tahun 2015 tentang Percepatan Pengisian JPT pada Kementerian/ Lembaga. Ketiga, transparan dalam prosesnya. Dalam proses seleksi calon JPT, masyarakat/publik mengetahui 
peserta seleksi atau calon JPT, tahaptahap pelaksanaan seleksi, dan hasil dari setiap tahapan seleksi. Terkait dengan peserta seleksi atau calon JPT, masyarakat dapat melaporkan rekam jejak mereka kepada Panitia Seleksi (Pansel), sehingga Pansel dapat mempertimbangkan keikutsertaan atau kelulusan peserta seleksi atau calon JPT.

Hasil penelitian (Yahya \& Mutiarin, 2015) bahwa dalam pengisian jabatan struktural eselon II di lingkungan Pemda DIY dilakukan dengan tata cara pengisian jabatan struktural tersendiri. Pengisian jabatan struktural eselon II tersebut dilakukan dengan promosi model lelang jabatan. Proses promosi jabatan struktural eselon II Pemda DIY telah terbuka bagi PNS di luar Pemda DIY. Pemda DIY menerapkan promosi model lelang jabatan struktural agar mendapatkan aparatur sipil negara yang berkinerja baik dan kompetensinya sesuai dengan jabatan struktural yang lowong dilingkungan pemerintah.

Ada perbedaan pemaknaan terbuka di antara promosi model lelang jabatan yang dilakukan oleh Pemda DIY dan UU ASN No. 5 tahun 2014. Keterbukaan yang dimaksudkan oleh UU ASN adalah keterbukaan atau kebebasan bagi semua aparatur sipil negara yang memenuhi syarat untuk dapat melamar mengikuti proses seleksi jabatan struktural yang lowong tersebut.

Sedangkan keterbukaan yang dilakukan dalam promosi model lelang jabatan struktural Pemda DIY dengan memilih kandidat-kandidat yang berkompeten dan dianggap pantas untuk dapat mengemban jabatan struktural yang lowong tersebut. Pemilihan kandidat ini dilakukan dengan mencari informasi atau membuat profil dengan menelusuri nama-nama yang dianggap pantas oleh BAPERJAKAT yang dibantu bidang promosi dan mutasi BKD Pemda DIY.

Berbeda halnya dengan DIY, model pelaksanaan lelang jabatan eselon III dan IV di Dinas Bina Marga dan Dinas Pemuda dan Olahraga Provinsi Jawa Tengah menggunakan konsep talent scouting untuk mencari kader talent pool yang layak menduduki jabatan struktural di lingkungan Pemerintah Provinsi Jawa Tengah. Selain itu, konsep talent scouting yang digunakan dalam lelang jabatan tersebut juga berdampak efektif dan sesuai dengan kebutuhan pemerintah provinsi akan pejabat yang dapat menduduki jabatan teknis yang didukung dengan spesifikasi keahlian dan kapabilitas (Nurwana, 2016).

Temuan yang sama juga dihasilkan oleh penelitian (Herawati, 2016) meneliti tentang Evaluasi Lelang Jabatan Camat Dan Lurah Pemerintah Provinsi DKI Jakarta. Lelang jabatan adalah bentuk dari promosi jabatan yang dilakukan secara transparan dan selektif. Transparan karena dilakukan secara terbuka dan setiap orang yang memiliki syarat administratif berupa tingkat kepangkatan dan golongan, diperbolehkan mendaftarkan diri untuk mengisi lowongan yang tersedia. Selektif karena proses pelaksanaannya dilakukan uji kompetensi ataupun fit and proper test. Lelang jabatan memiliki nilai positif dalam rangka reformasi birokrasi yaitu untuk merekrut ataupun menempatkan pejabat eselon yang memiliki kompetensi dan 
profesionalitas yang memadai di DKI Jakarta.

Rekomendasi dari penelitian ini Lelang jabatan meski diyakini dilakukan transparan dan selektif dan dilakukan secara profesional, ada satu nilai yang kurang dari proses Lelang Jabatan, yakni belum adanya konsep partisipatif. Artinya dengan kata lain di beberapa tahapan sebenarnya masyarakat/publik bisa diikutsertakan, paling minimal memberikan tanggap terbuka yang mekanismenya disepakati merupakan bagian dari kebijakan Pengisian Jabatan Tinggi secara Terbuka berdasarkan sistem Merit dengan tidak diskriminatif serta partisipatif.

Pada prinsipnya pengisian jabatan pimpinan tinggi pratama dilakukan secara terbuka dan kompetitif di kalangan PNS dengan memperhatikan syarat kompetensi, kualifikasi, kepangkatan, pendidikan dan pelatihan, rekam jejak jabatan, dan integritas serta persyaratan jabatan lain sesuai dengan ketentuan peraturan perundang-undangan yang dilakukan secara terbuka dan kompetitif pada tingkat nasional atau antar kabupaten/kota dalam 1 (satu) provinsi.

Pelaksanaan sistem promosi secara terbuka yang dilakukan melalui pengisian jabatan yang lowong secara kompetitif dengan didasarkan pada sistem merit. Dengan sistem merit tersebut, maka pelaksanaan promosi jabatan didasarkan pada kebijakan dan Manajemen ASN yang dilakukan sesuai dengan kualifikasi, kompetensi, dan kinerja secara adil dan wajar dengan tanpa membedakan latar belakang politik, ras, warna kulit, agama, asal usul, jenis kelamin, status pernikahan, umur, atau kondisi kecacatan. Ada 9 prinsip dalam sistem merit menurut Permenpan RB No. 13 Tahun 2014 Tentang Tata Cara Pengisian Jabatan Pimpinan Tinggi Secara Terbuka Di Lingkungan Instansi Pemerintah dalam rangka pengisian jabatan, yaitu : (1) Melakukan rekrutmen, seleksi dan prioritas berdasarkan kompetisi yang terbuka dan adil; (2) Memperlakukan Pegawai Aparatur Sipil Negara secara adil dan setara; (3) Memberikan remunerasi yang setara untuk pekerjaan-pekerjaan yang setara dan menghargai kinerja yang tinggi; (4) Menjaga standar yang tinggi untuk integritas, perilaku dan kepedulian untuk kepentingan masyarakat; (5) Mengelola Pegawai Aparatur Sipil Negara secara efektif dan efisien; (6) Mempertahankan atau memisahkan Pegawai Aparatur Sipil berdasarkan kinerja yang dihasilkan; (7) Memberikan kesempatan untuk mengembangkan kompetensi kepada Pegawai Aparatur Sipil Negara; (8) Melindungi Pegawai Aparatur Sipil Negara dari pengaruhpengaruh politis yang tidak pantas/tepat; dan (9) memberikan perlindungan kepada Pegawai Aparatur Sipil dari hukum yang tidak adil dan tidak terbuka.

Meskipun demikian, seleksi terbuka masih mendapatkan beberapa kelemahan, sehingga diperlukan sebuah evaluasi. Hasil kajian yang dilakukan oleh (Irfan, 2017), setidaknya ada tiga kelemahan dalam seleksi terbuka ini, yaitu: Pertama, biaya yang cukup mahal. Biaya yang diperlukan dalam proses seleksi terbuka JPT dialokasikan untuk biaya operasional Pansel dan Sekretariat Pansel. Biaya lain, dialokasikan untuk membayar pihak ketiga berkenaan dengan tes atau ujian yang diperlukan dalam penelusuran kompetensi calon JPT 
(misal asessment center). Besarnya biaya yang dialokasikan dalam penilaian kompetensi JPT bergantung pada harga yang diberikan oleh pihak ketiga, yang berkenaan dengan berapa materi yang akan diujikan dan metode yang digunakan.

Disisi lain, biaya juga dikeluarkan peserta seleksi untuk melakukan tes kesehatan pada instansi/lembaga kesehatan yang diakui pemerintah (tes kesehatan jasmani, tes kepribadian atau tes kejiwaan dan tes bebas narkoba). Kedua, pembatasan atau (demarkasi) terhadap calon peserta seleksi JPT. Hal yang biasa dilakukan oleh suatu instansi untuk membatasi peserta dari luar instansi adalah dengan memberlakukan persyaratanpersyaratan yang sulit dipenuhi oleh calon-calon peserta seleksi dari luar instansi tersebut. Ada kecenderungan masing-masing instansi pemerintah menginginkan lowongan jabatan di lingkungan instansinya diisi dari orang dalam.

Hal ini tentu mengabaikan salah satu tujuan dari pelaksanaan open recruitment sebagai sarana pengejawantahan merit system dan open career system di lingkungan PNS. Ketiga, waktu yang cukup lama. Waktu untuk melaksanakan satu tahap ke tahap berikutnya cukup memakan waktu. Hal ini disebabkan oleh beberapa hal: (1) pemenuhan kuota calon peserta seleksi terhadap formasi jabatan yang kosong; (2) belum adanya pedoman penilaian pada setiap tes (ujian) juga menyebabkan keputusan penilaian hasil tes memerlukan waktu yang cukup lama; (3) Penentuan seorang Pejabat Pimpinan Tinggi oleh Pejabat Pembina Kepegawaian (PPK) sering sekali memerlukan waktu yang cukup lama.
Namun demikian, hasil dari seleksi terbuka jabatan ASN sebagaimana dimaksud di atas diharapkan menghasilkan ASN yang profesional, dan bebas dari intervensi politik. Untuk menghasilkan ASN profesional proses seleksinya harus dilaksanakan berdasarkan sistem merit. Poin penting dalam sistem merit adalah penyelenggaraan segala sesuatu kebijakan dan aktivitas dalam kelembagaan negara pada level pusat dan daerah yang berpegang teguh pada prinsip profesionalisme (Dwiyanto, 2015). Sistem ini memberikan kesempatan kepada siapa pun para calon kandidat untuk melamar dan mendapatkan perlakuan yang sama sejauh mereka memenuhi kualifikasi sebagaimana di atur dalam perundang-undangan. Oleh karena itu, dampak dari pelaksanaan sistem merit ini dapat menghasilkan ASN yang unggul dan profesional dapat membawa negara Indonesia berdaya saing dengan negara-negara lainnya.

\section{Kesimpulan}

Tujuan utama dalam seleksi terbuka untuk menghasil pejabat yang berkompetensi dan bebas dari intervensi politik belum menjawab permasalahan subtansinya. Sistem seleksi terbuka hanya menjaring kandidat secara terbuka sesuai dengan persyaratan sebagaimana tercantum dalam peraturan perundang-undangan. Namun tahapan seleksi terbuka ini hanya mengusulkan tiga calon yang telah diseleksi. Tahapan selanjutnya ialah menyerahkan hasil seleksi tersebut kepada pejabat pembina kepegawaian dalam hal ini Gubernur dan Bupati/Walikota dalam lingkup Pemerintahan Provinsi dan Kabupaten/Kota. 
Hal ini menjadi dikotomi untuk bebas dari intervensi politik terhadap birokrasi, apabila pejabat pembina kepegawaian daerah masih di jabat oleh Gubernur dan Bupati/Walikota. Dikotomi politik dan administrasi masih sulit dipisahkan. Sehingga, seleksi terbuka jabatan ASN belum menyelesaikan persoalan intervensi politik terhadap birokrasi. Oleh karena itu rekomendasi dari tulisan ini adalah diperlukan peninjauan ulang terhadap kebijakan seleksi terbuka jabatan ASN. Sehingga, benar-benar menghasilkan ASN yang berkompeten dan bebas dari intervensi politik.

\section{Referensi}

Basyar, A. H. (2018). Relevansi Kualitas Birokrasi dan Manajemen Kinerja. https://seknasfitra.org/wpcontent/uploads/2018/12/rb.pdf.

Dwiyanto, A. (2015). Reformasi Birokrasi Kontekstual Kembali ke Jalur yang Benar. Gadjah Mada University Press.

G.Mulgan, \& Albury, D. (2003). Innovation in the Public Sector. Prime Minister Strategy Unit. Cabinet Office.

Handoko, T. H. (2012). Manajemen (2nd ed.). BPFE.

Hasibuan, M. S. (2001). Manajemen Sumber Daya Manusia. Bumi Aksara.

Herawati, N. R. (2016). Evaluasi Lelang Jabatan Camat dan Lurah Pemerintah Provinsi DKI Jakarta. Jurnal Ilmiah Ilmu Pemerintahan, 2(2), 51-60.
Irfan, M. (2017). Seleksi Terbuka Jabatan Pimpinan Tinggi di Lingkungan Instansi Pemerintah. Civil Aparatur Policy Brief Badan Kepegawaian Negara (pp. 1-4).

KASN. (2018). Pengawasan Netralitas Aparatur Sipil Negara 2018 (1st ed.). Komisi Aparatur Sipil Negara.

KPK. (2014). Laporan Hasil Kajian Relasi Dana Bansos dan Hibah PBD dengan Pilkada.

Lynn, L. (1997). Innovation and the public interest: Insight form the Private Sector. In \& R. D. B. A. A. Altshuler (Ed.) Innovation in American Government: Challenges, Opportunities, and Dilemmas. The Brookings Instituions.

Mintzberg, H. (2000). The Structuring of of Organization, A Synthesis of the Research. Prentice Hall, Inc.

Nurwana, M. A. (2016). Evaluasi Lelang Jabatan di Lingkungan Pemerintah Provinsi Jawa Tengah Tahun 2013-2014 (Studi Penelitian Pada Eselon III dan IV Dinas Bina Marga dan Dinas Pemuda dan Olahraga). Journal of Politic and Government Studies, $5(2)$.

Osborne, D. dan T. G. (1992). Reinventing Government: How the Entrepreneurial Spirit is Transforming the Public Sector, diterjemahkan oleh Abdul Rosyid.1996. Mewirausahakan Birokrasi: Mentransformasikan Semangat Wirausaha ke dalam Sektor Publik. Pustaka Binaman Pressido.

Rogers, E. M. (2003). Diffusion of 
Innovations (5th edition). The Free Press.

Schuler, \& J. (1997). Manajemen Sumber Daya Manusia. Alfabeta.

Siagian, S. P. (2003). Manajemen Sumber Daya Manusia. Bumi Aksara.

Taufik, \& Astuti, R. S. (2019). Innovation Management of Organic Waste into Methane in Landfill Gampong Java Banda Aceh. Proceedings of the 4th International Conference on Indonesian Social and Political Enquiries, ICISPE 201921-22 October 2019, Semarang, Central Java, Indonesia. https://doi.org/https://doi.org/ 10.4108/eai.21-102019.2294450

Yahya, M. R., \& Mutiarin, D. (2015). Model Lelang Jabatan Di Pemerintah Daerah Daerah Istimewa Yogyakarta. Jurnal Ilmu Pemerintahan Dan Kebijakan Publik, 2(2). https://doi.org/https://doi.org/ 10.18196/jgpp.2015.0035

Zed, M. (2004). Metode Penelitian Kepustakaan. Yayasan Obor Indonesia. 